\title{
Original Research \\ Impact of Climate Change on Groundwater Resources in a Young Glacial Multi-Aquifer System
}

\begin{abstract}
Beata Jaworska-Szulc*
Department of Geotechnics, Geology and Maritime Engineering, Faculty of Civil and Environmental Engineering, Gdansk University of Technology, Narutowicza 11/12, 80-233 Gdansk, Poland

Received: July 25, 2015

Accepted: August 25, 2015

Abstract

The aim of this study was to evaluate the trends of climate change on the Kashubian Lake District and to determine the impact of expected trends on groundwater resources. The analysis of trends in temperature and precipitation was conducted for the six-decade history of meteorological measurements at the weather station in Koscierzyna. The analysis shows the trend of temperature increase of $+0.0182^{\circ} \mathrm{C} /$ year. The highest increase in temperature is observed in the months from January to May, and in July and August. Annual precipitation also shows a growing trend. This is on average $1.847 \mathrm{~mm} /$ year, while the largest increase relates to the months from January to March and from October to December. These trends may contribute to an increase in the recharge rate. Precipitation grows mainly in the non-growing season. If the current trends are maintained, the sum of precipitation involved in the groundwater recharge will probably increase by $36 \mathrm{~mm}(5.5 \%)$ over the next 50 years. The groundwater flow model (MODFLOW) calculation made for these projections showed primarily a tendency for increased descending seepage between aquifers and a slight decrease in upward flow. The most significant changes are observed in the shallow layer, were spring outflows increases by $12 \%$, and the water table rises by about one meter.
\end{abstract}

Keywords: climate change, groundwater resources, groundwater flow, young glacial area

\section{Introduction}

The impact of climate change on groundwater resources is becoming a more common subject of hydrogeological studies. As noted by Green et al. [1], global climate change has implications for both water quality and quantity; unfortunately, feedback from groundwater and climate constitute a knowledge gap. The aquifers, because of their large storage capacity, are potentially less sensitive to climate change then surface-water bodies. Although many climate-change studies have predicted reduced recharge, the effects of climate change on recharge may not necessarily be negative in

*e-mail: bejaw@pg.gda.pl all aquifers during all periods of time [1]. While many studies have shown a predicted reduction in recharge rates, other studies have shown an increase $[2,3]$. This discrepancy results from the regional differences in climate change as well as from different approaches of climate change predictions. Interesting results were obtained by Jackson et al. [4], who estimated changes in the recharge of a chalk aquifer in the UK on the basis of projections of as many as 13 different models of global climate change. Changes in the aquifer recharge ranged from $-26 \%$ to $+31 \%$ (simulations up to 2080). At the same time, 10 of the listed models predicted a decline in recharge, and three models predicted an increase. Taylor et al. [5] consider that current uncertainty about the impacts of climate on recharge derive not 
only from substantial uncertainty in the global climate model (GCM) projections of precipitation, but also from that associated with the downscaling of GCM projections and the hydrological models used. Beven [6] also draws attention to the limited credibility of popular climate models. However, tracking trends of climate change is an extremely important element in predicting changes in groundwater resources. In spite of the above-mentioned doubts about climate models, the review paper on the impact of climate change on groundwater [7] has suggested that global and regional climate models (GCMs and RCMs) should be used as a tool to generate climate forecasts and projections of groundwater resources. Holman et al. [7] also suggest that as many different forecasts and climate models as possible should be included in order to eliminate extremely pessimistic or optimistic projections. A comprehensive approach to the analysis of changes in climate factors and their impact on changes in groundwater recharge is also suggested.

The IPCC reports $[2,3]$ do not specify any global trends in groundwater resource formation. They emphasize, however, that changes in river outflow have more influence on changes in groundwater table levels than recharge changes directly related to precipitation [2]. Outflow in the northern hemisphere shows a rather positive trend $[2,3]$.

The aim of this research was to identify the trends of climate change on the basis of meteorological observations in the Kashubian Lake District, in order to compare them with trends described by climate models [2,3] and to assess the impact of defined trends on groundwater resources in the multi-aquifer system. The analysis of trends in temperature and precipitation was conducted for the six-decade history of meteorological measurements at the weather station in Koscierzyna. The obtained positive trends in temperature and precipitation are consistent with the predicted climate change in the IPCC 2013 report [3], calculated by climate models. In the context of the groundwater resources formation, these positive trends in temperature and precipitation may contribute to an increase in groundwater recharge primarily because the precipitation increase in the nongrowing season. Therefore, the impact of increased recharge was checked on the groundwater flow model. As commonly done for groundwater flow system analysis, the USGS MODFLOW model [8] was used. Model simulations in terms of increased recharge showed changes in the groundwater flow of the entire aquifer system.

\section{Material and Methods}

\section{Research Area}

The Kashubian Lake District was chosen for research because it is the recharge area for the regional aquifer system [9]. This area (Figs. 1 and 2) is the highest and mor-

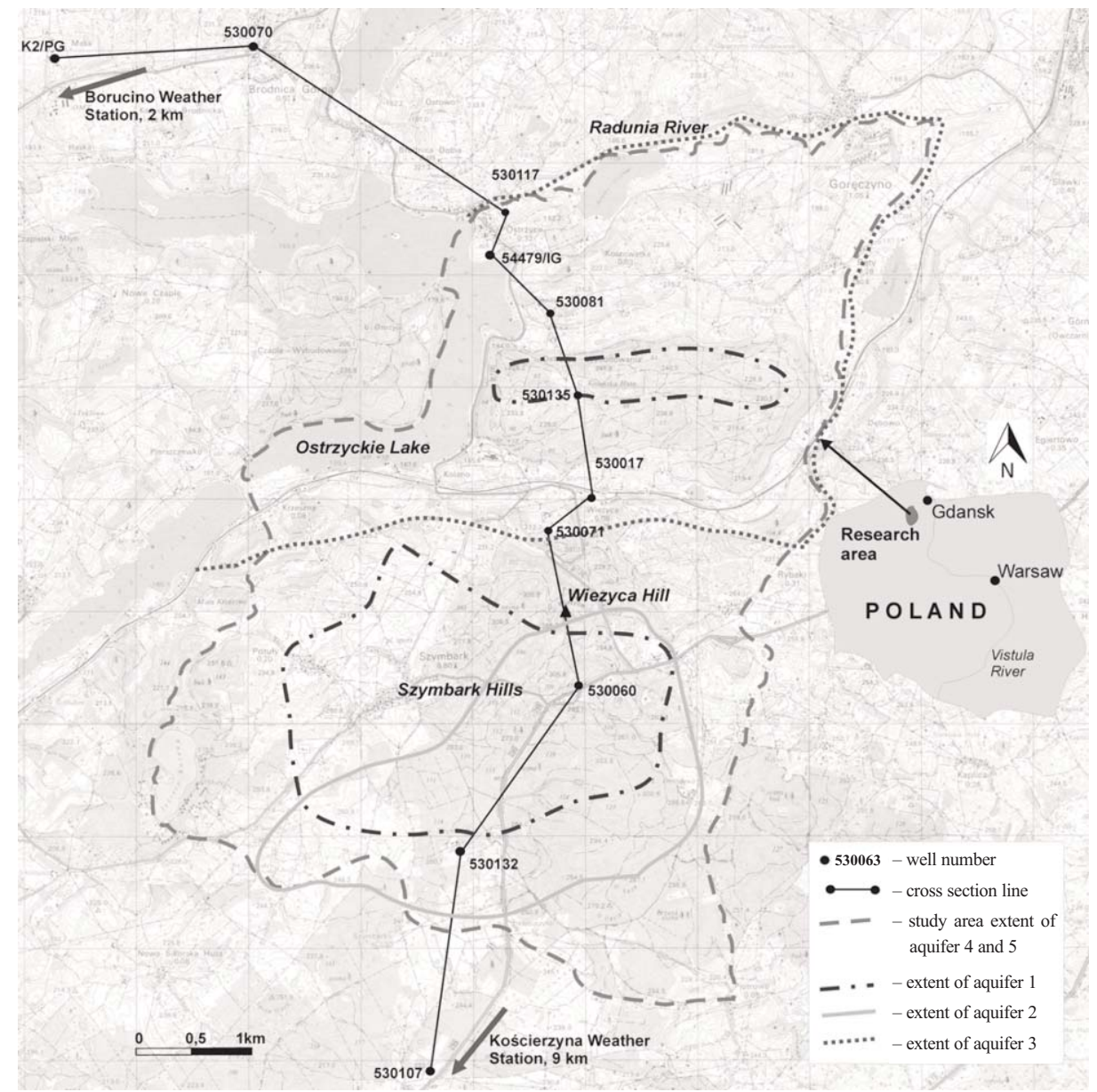

Fig. 1. Central part of Kashubian Lake District - the research area, approximate extent of aquifers. 


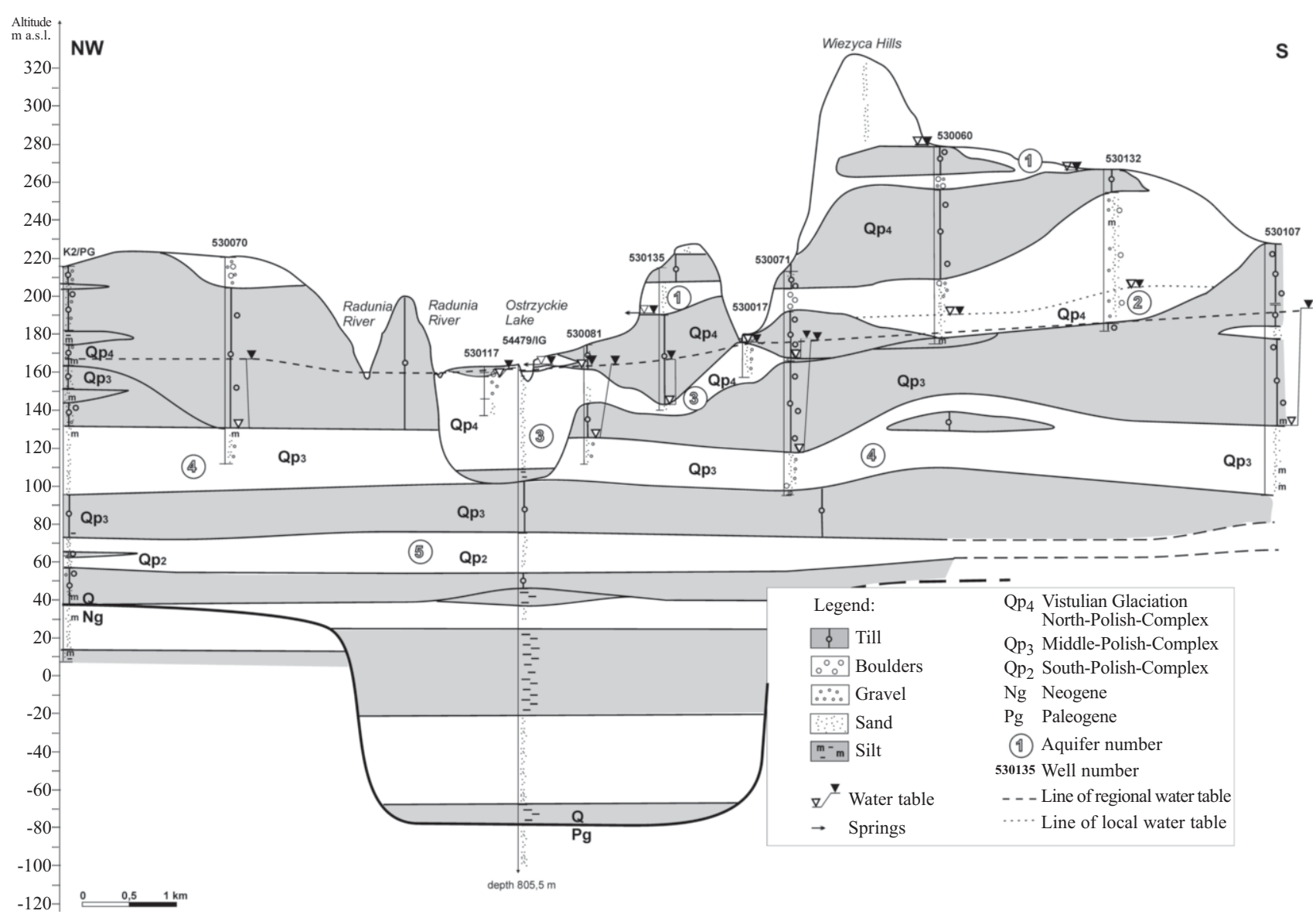

Fig. 2. Hydrogeological cross-section.

phologically most diverse part of the North European Plain. The varied young glacial landform is the result of glacier activity in the Vistulian Glaciation (11.7-115 Ka, [10]). Recent studies [11] have described Wiezyca and neighboring hills as crevasse accumulation forms. The impressive elevation of these hills is principally associated with the high thickness of Pleistocene deposits. An interesting, hilly landform is also formed by ground and undulated moraine, at elevations from $200 \mathrm{~m}$ above sea level to $250 \mathrm{~m}$ above sea level. Flat ground moraines virtually do not exist in the analyzed area. Postglacial hills are cut by deep tunnel valleys, kame terraces, and small outwash sand plains that are found along the edges of the tunnel valleys.

The thickness of quaternary deposits reaches $250 \mathrm{~m}$, and there are alternate glacial and fluvioglacial deposits of the Vistulian glaciation (11.7-115 Ka), middle Polish complex glaciations $(115 \mathrm{Ka}-440 \mathrm{Ka})$, and south-Polish complex glaciations (440Ka-950Ka, [10]). Cyclic glacial and fluvioglacial sedimentation processes have left alternatelyoccurring series of permeable and impermeable deposits. Consequently, five more-or-less continuous aquifers have been distinguished (Table 1, Fig. 2). The first includes local groundwater, which occurs only in the most elevated parts of the hills, perched at the highest level of glacial till of the Vistulian glaciation (perched groundwater). Perched groundwater occurs at 250 to $270 \mathrm{~m}$ above sea level, on a small area in the crevasse accumulation deposits or in the fluvioglacial deposits of the Vistulian glaciation. The thickness of this aquifer is of a few meters, and often less than one meter. The second aquifer also occurs mainly in the central part of the studied area (Figs. 1 and 2), in the fluvioglacial deposits of the Vistulian glaciation (outwash sand layer). It forms a local water-bearing structure, not continuous in some places, but of considerable thickness, sometimes exceeding 30 meters (Fig. 2). The water table occurs at a depth of over 50 meters, usually at 180 to $200 \mathrm{~m}$ above sea level. The third aquifer is also formed by Vistulian glaciation deposits (valley layer), but it occurs mainly in tunnel valleys and meltwater valleys (i.e., in the northern part of the studied area). Here, it constitutes the first aquifer. Aquifer thickness sometimes exceeds 50 meters. The fourth layer is continuous in the area, and groundwater occurs in the middle-Polish complex glaciation deposits. Locally in tunnel valleys, it has hydraulic connections with the valley (third) layer. The thickness is usually about 20-40 meters. The top elevation is usually at 110-160 $\mathrm{m}$ above sea level. The fifth aquifer distinguished in the south-Polish complex glaciation deposits occurs at about $60-70 \mathrm{~m}$ above sea level. It has a low thickness of about 10-20 meters, but occurs throughout the research area.

Attention is drawn to the high position of the first aquifer in relation to the main base levels of drainage, which are the tunnel valley lakes and the Radunia River, 
Table 1. Distinguished aquifers in Quaternary deposits.

\begin{tabular}{|c|c|c|c|c|}
\hline $\begin{array}{l}\text { Aquifer } \\
\text { number }\end{array}$ & Stratigraphy & Groundwater occurrence conditions & $\begin{array}{c}\text { Top elevation } \\
\text { (m a.s.l.) }\end{array}$ & $\begin{array}{l}\text { Horizontal hydraulic } \\
\text { conductivity mean (range) }\end{array}$ \\
\hline 1 & \multirow{3}{*}{$\begin{array}{c}\mathrm{Qp}_{4} \text { Vistulian } \\
\text { Glaciation }\end{array}$} & $\begin{array}{l}\text { Perched groundwater: occurs locally, only in the most ele- } \\
\text { vated parts of the hills, perched at the highest level of glacial } \\
\text { till, thickness of the aquifer is of a few meters and often less } \\
\text { than one meter }\end{array}$ & $250-260$ & $\begin{array}{c}2.0 \times 10^{-4} \\
\left(2.8 \times 10^{-6}-4.2 \times 10^{-4}\right)\end{array}$ \\
\hline 2 & & $\begin{array}{l}\text { Outwash sand layer: occurs mainly in the central part of the } \\
\text { studied area, in the fluvioglacial deposits, forms a local } \\
\text { water-bearing structure, thickness exceeding } 30 \text { meters }\end{array}$ & $180-200$ & $\begin{array}{c}1.9 \cdot 10^{-4} \\
\left(8.6 \times 10^{-5}-2.6 \times 10^{-4}\right)\end{array}$ \\
\hline 3 & & $\begin{array}{l}\text { Valley layer: occurs mainly in tunnel valleys and meltwater } \\
\text { valleys, i.e., in the northern part of the studied area, thickness } \\
\text { sometimes exceeds } 50 \text { meters }\end{array}$ & $160-165$ & $\begin{array}{c}1.9 \times 10^{-4} \\
\left(3.3 \times 10^{-5}-5.2 \times 10^{-4}\right)\end{array}$ \\
\hline 4 & $\begin{array}{l}\mathrm{Qp}_{3} \text { Middle-Polish } \\
\text { Complex Glaciation }\end{array}$ & $\begin{array}{l}\mathrm{Qp}_{3} \text { layer: continuous in the studied area, locally in tunnel } \\
\text { valleys, it has hydraulic connections with the valley (third) } \\
\text { layer, the thickness is usually about } 20-40 \text { meters }\end{array}$ & $110-160$ & $\begin{array}{c}1.5 \times 10^{-4} \\
\left(1.4 \times 10^{-5}-3.1 \times 10^{-4}\right)\end{array}$ \\
\hline 5 & $\begin{array}{c}\mathrm{Qp}_{2} \text { South-Polish } \\
\text { Complex Glaciation }\end{array}$ & $\begin{array}{l}\mathrm{Qp}_{2} \text { layer: low thickness of about } 10-20 \text { meters, but is con- } \\
\text { tinuous throughout the research area }\end{array}$ & $60-70$ & $\begin{array}{c}1.0 \times 10^{-4} \\
\left(1.9 \times 10^{-5}-2.1 \times 10^{-4}\right)\end{array}$ \\
\hline
\end{tabular}

located at $160 \mathrm{~m}$ above sea level. The first level of perched groundwater occurs at about $250 \mathrm{~m}$ above sea level. It is the recharge area for deeper aquifers, without the discharge to surface waters. These are mainly endorheic evapotranspiration or absorptive areas. The perched groundwater shows a high sensitivity to climatic conditions. There is a clear correlation between the precipitation and groundwater levels, as was observed in the measurement wells.

\section{Groundwater Flow Model Simulation}

The ModFlow program configured with GMS 8.3 [8] was used for modelling groundwater flow. The first two aquifers occur locally only in the most elevated part of the study area, and have a very limited range (Fig. 1). The II-type boundary condition $\mathrm{Q}=0$ was used here. Rivers were defined by the III-type river condition. In the third aquifer (on the border with Ostrzyckie Lake) the III-type condition GHB (General Head Boundary) was adopted. In the two deeper aquifers, 4 and 5 (which are continuous throughout the study area), the II-type condition $\mathrm{Q}=0$ was used at the boundaries running parallel to the groundwater flow, and the III-type condition GHB was adopted on the perpendicular borders.

Five Quaternary aquifers and four poorly permeable interbeddings (usually glacial tills) were distinguished in the model. The layers of tills were marked with the numbers of aquifer separated by them, e.g., tills 2-3-4 separate aquifers 2, 3, and 4 (Fig. 3), according to the range of their occurrence. The model has a total of eight layers:

- First layer of the model is the first aquifer, perched groundwater

- Second layer of the model is the layer of tills 1-2-3, separating the first, second, and third aquifers

- Third layer of the model: the second aquifer, the outwash sand level; and the third aquifer, the valley level

- Fourth layer of the model is the layer of tills 2-3-4 separating the second, third, and fourth aquifers,
- Fifth layer of the model is the fourth aquifer

- Sixth layer of the model is the layer of tills 4-5 separating the fourth and fifth aquifers

- Seventh layer of the model is the fifth aquifer

- Eighth layer of the model is the layer of tills 5, the bottom of the model

Vertical hydraulic conductivity for the aquifers was defined based on pumping tests in drilled wells. Mean values for individual aquifers are generally in the range from $1.1 \times 10^{-4} \mathrm{~m} / \mathrm{s}$ to $1.9 \times 10^{-4} \mathrm{~m} / \mathrm{s}$ (Table 1 ). The value of hydraulic conductivity for glacial tills was assumed with a wide range from $2.85 \times 10^{-10}$ to $3.06 \times 10^{-5} \mathrm{~m} / \mathrm{s}$, average $1.42 \times 10^{-8} \mathrm{~m} / \mathrm{s}$.

Differences between the groundwater table levels in measurements and values obtained from model studies are typically less than $1 \mathrm{~m}$. The calibration errors are relatively low, mean error is $0.12 \mathrm{~m}$, and mean absolute mean error is $0.67 \mathrm{~m}$. This indicates a good representation of the complex young-glacial geological structure of the analyzed area.

Groundwater flow balance obtained in the model (Fig. 3) shows that the first aquifer (perched groundwater) is recharged by the infiltration of precipitation, and the entire outflow includes vertical percolation (descent seepage) to the second aquifer, with only a small share of the spring outflow. The second aquifer (outwash sand layer) is recharged by the infiltration of precipitation, outside the reach of the first aquifer, and the seepage from surface waters located above the groundwater level. The groundwater from the second aquifer is discharged to the fourth aquifer. The third aquifer (valley layer) is also recharged by the infiltration of precipitation, infiltration of surface waters, and upward flow from the fourth aquifer. Near tunnel valley lakes, the ascent seepage may occur directly in contact zones of both aquifers. The outflow from the fourth aquifer is mainly the drainage of Radunia River and Ostrzyckie Lake, the outflow from springs, and discharge to the fifth aquifer. The groundwater balance in the two 
deeper aquifers, the fourth and fifth, consists mainly of vertical seepage between the aquifers, i.e., descent seepage from the more shallow layers to deeper layers on moraine hills and ascending seepage in the area of drainage. The fourth aquifer is also recharged by the lateral inflow, while in the fifth aquifer the lateral inflow is negligible, which indicates that the boundary of the research area is located close to this aquifer's watershed.

Since the study area is low urbanized there are only two small groundwater intakes where total pumping does not exceed $17.8 \mathrm{~m}^{3} / \mathrm{h}$ (Fig. 3).

\section{Results and Discussion}

\section{Trends in Climate Change in the Multi-Year Period 1952-2012}

The humid continental climate of the Kashubian Lake District is influenced by both the Atlantic Ocean and the Eurasian continent. The course of weather events is dependent mainly on air masses coming from above the North Atlantic, where two pressure centers are located to condition regional atmospheric circulation: the Azores High and the Icelandic Low [12]. The most relevant phenomena affecting climate variability in diverse periods and time scales are those related to the large-scale atmospheric circulation such as the North Atlantic Oscillation [3]. The NAO's influence on winter temperature anomalies is very relevant in Northern and Central Europe. The cold season precipitation (October to March) interannual variability is controlled mainly by NAO [3].
Based on data provided by the Institute of Meteorology and Water Management in Poland, an analysis of trends in temperature and precipitation was conducted for the sixdecade history of meteorological measurements at the weather station in Koscierzyna (Fig. 4). The station is located just a few kilometers from the southern boundary of the studied area (Fig. 1). Similarly to the analyses performed for the neighboring station in Borucino [12], there is a steady trend of temperature increase. However, the analysis carried out for the six-decade period (1952-2012) shows a temperature increase of $+0.0182^{\circ} \mathrm{C} /$ year, which is half that achieved by Miętus [12] in the four decades from 1961 to $2000\left(+0.0376^{\circ} \mathrm{C} /\right.$ year $)$. Based on the analysis of temperature trends in Koscierzyna (Figs. 4 and 5), it can be assumed that the average annual temperature will increase by $0.9^{\circ} \mathrm{C}$ over the next 50 years (Table 2) if the current trends are maintained. The highest increase in temperature is observed in the months from January to May, and in July and August. However, the trends decrease in June and October, while in June the change is small and can be regarded as negligible.

The analysis of the average monthly and annual precipitation in Koscierzyna for the period 1952-2012 also shows a growing trend (Table 3, Figs. 4 and 6). This is an average of $1.847 \mathrm{~mm} /$ year; while the largest increase relates to the months from January to March and from October to December, a slightly smaller increase is also observed from May to July. A slight downward trend is observed in April, August, and September.

The trends in temperature and precipitation in Koscierzyna are consistent with the predicted climate change in the IPCC 2013 report [3] (Table 4). It is much

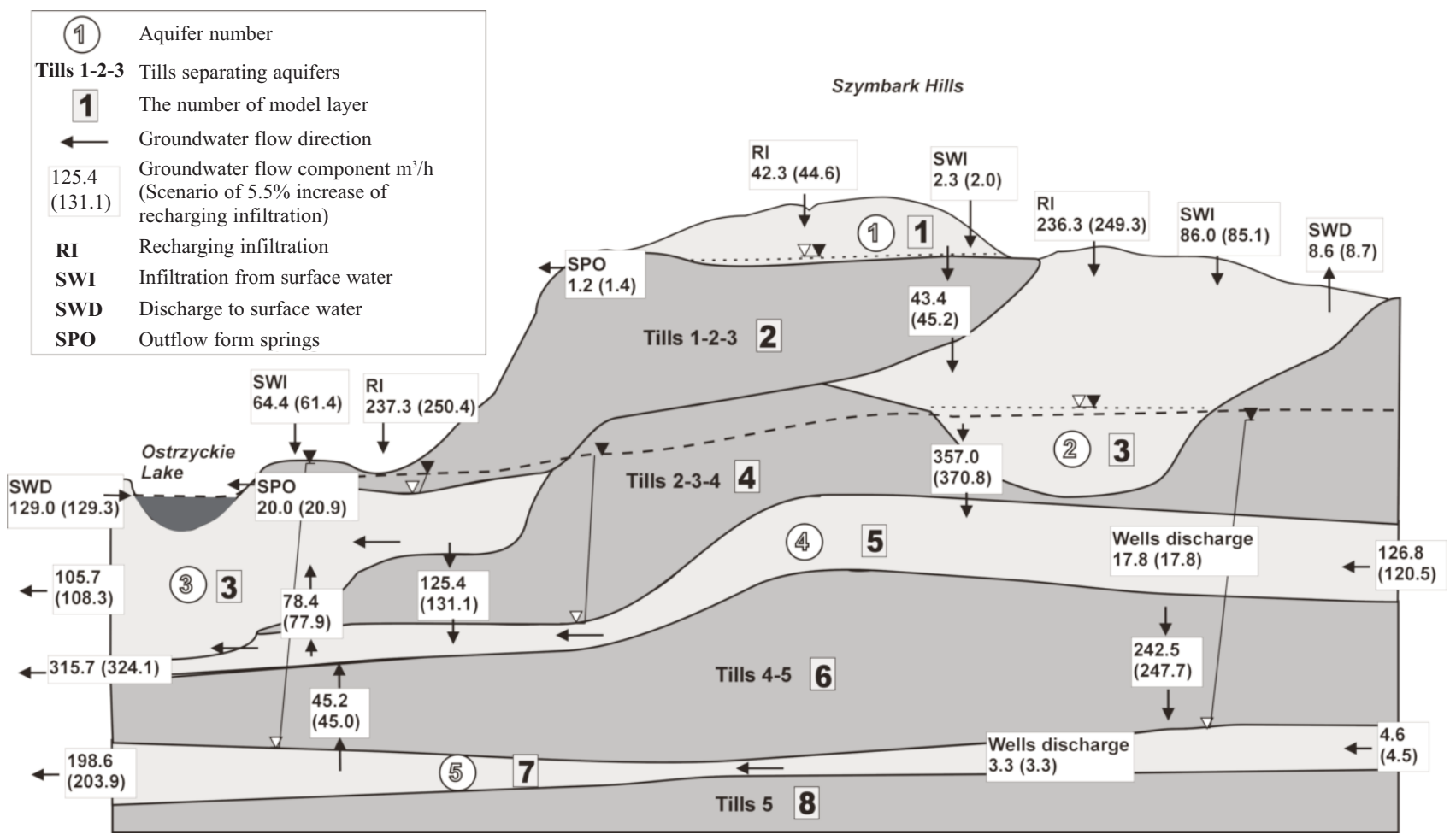

Fig. 3. Simplified diagram of groundwater flow. 
Table 2. Values of average monthly and annual temperatures and trends in their changes for the weather station in Koscierzyna, based on analysis of 1952-2012.

\begin{tabular}{|c|c|c|c|c|c|}
\hline Time & $\begin{array}{c}\text { Average monthly and } \\
\text { annual temperatures } \\
{\left[{ }^{\circ} \mathrm{C}\right]}\end{array}$ & $\begin{array}{l}\text { Maximum average } \\
\text { monthly and annual } \\
\text { temperatures }\left[{ }^{\circ} \mathrm{C}\right]\end{array}$ & $\begin{array}{l}\text { Minimum average } \\
\text { monthly and annual } \\
\text { temperatures }\left[{ }^{\circ} \mathrm{C}\right]\end{array}$ & $\begin{array}{c}\text { Trend in temperatures } \\
\text { changes } \\
{\left[{ }^{\circ} \mathrm{C} / \text { year }\right]}\end{array}$ & $\begin{array}{c}\text { Possible change in } \\
\text { temperature over } 50 \\
\text { years }\left[{ }^{\circ} \mathrm{C}\right]\end{array}$ \\
\hline I & -2.60 & 2.70 & -10.80 & 0.0268 & 1.34 \\
\hline II & -2.35 & 4.30 & -10.00 & 0.037 & 1.85 \\
\hline III & 0.91 & 5.30 & -3.70 & 0.0332 & 1.66 \\
\hline IV & 6.04 & 10.70 & 3.10 & 0.0363 & 1.82 \\
\hline $\mathrm{V}$ & 11.42 & 15.30 & 8.00 & 0.0288 & 1.44 \\
\hline VI & 14.89 & 17.50 & 12.70 & -0.0018 & -0.09 \\
\hline VII & 16.72 & 20.80 & 13.30 & 0.027 & 1.35 \\
\hline VIII & 16.14 & 19.70 & 13.50 & 0.0239 & 1.2 \\
\hline IX & 12.05 & 15.20 & 9.30 & 0.0054 & 0.27 \\
\hline$X$ & 7.50 & 10.80 & 4.10 & -0.0118 & -0.59 \\
\hline XI & 2.58 & 5.50 & -2.10 & 0.0084 & 0.42 \\
\hline XII & -0.97 & 4.10 & -7.80 & 0.0055 & 0.28 \\
\hline Year & 6.86 & 8.46 & 5.29 & 0.0182 & 0.91 \\
\hline
\end{tabular}

more difficult to detect global changing trends in precipitation due to their high natural variability [13]. However, most of the global models of climate scenarios (IPCC 2013, chapter 14 [3]) show a positive trend in precipitation in Central Europe.

In the context of the groundwater resources formation, these positive trends in temperature and precipitation may contribute to an increase in groundwater recharge - primarily because of precipitation increase in the non-growing season. The study on the terrain evaporation conducted (Table 3) at the meteorological station in Borucino (Fig. 1) showed that during the growing season, evaporation constitutes on average $94 \%$ of precipitation. However, in May and June evapotranspiration exceeds precipitation, while
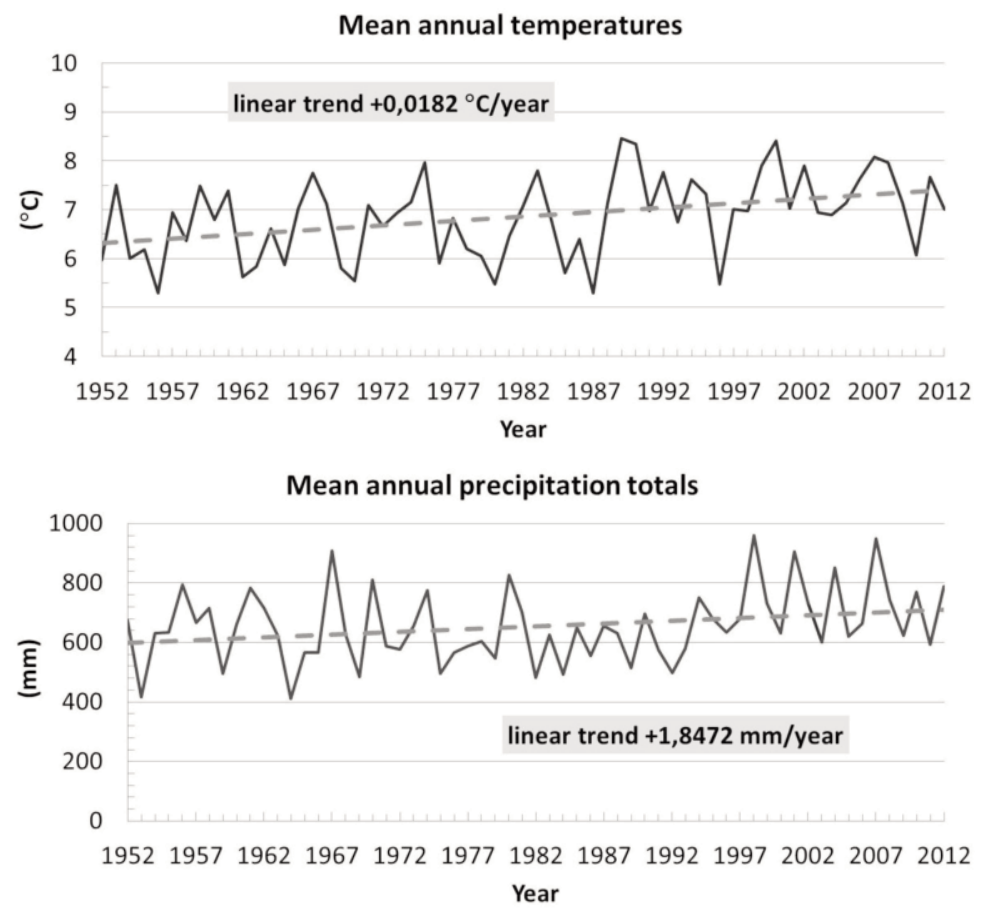

Fig. 4. Mean annual temperatures and precipitation totals in Koscierzyna, 1952-2012. 

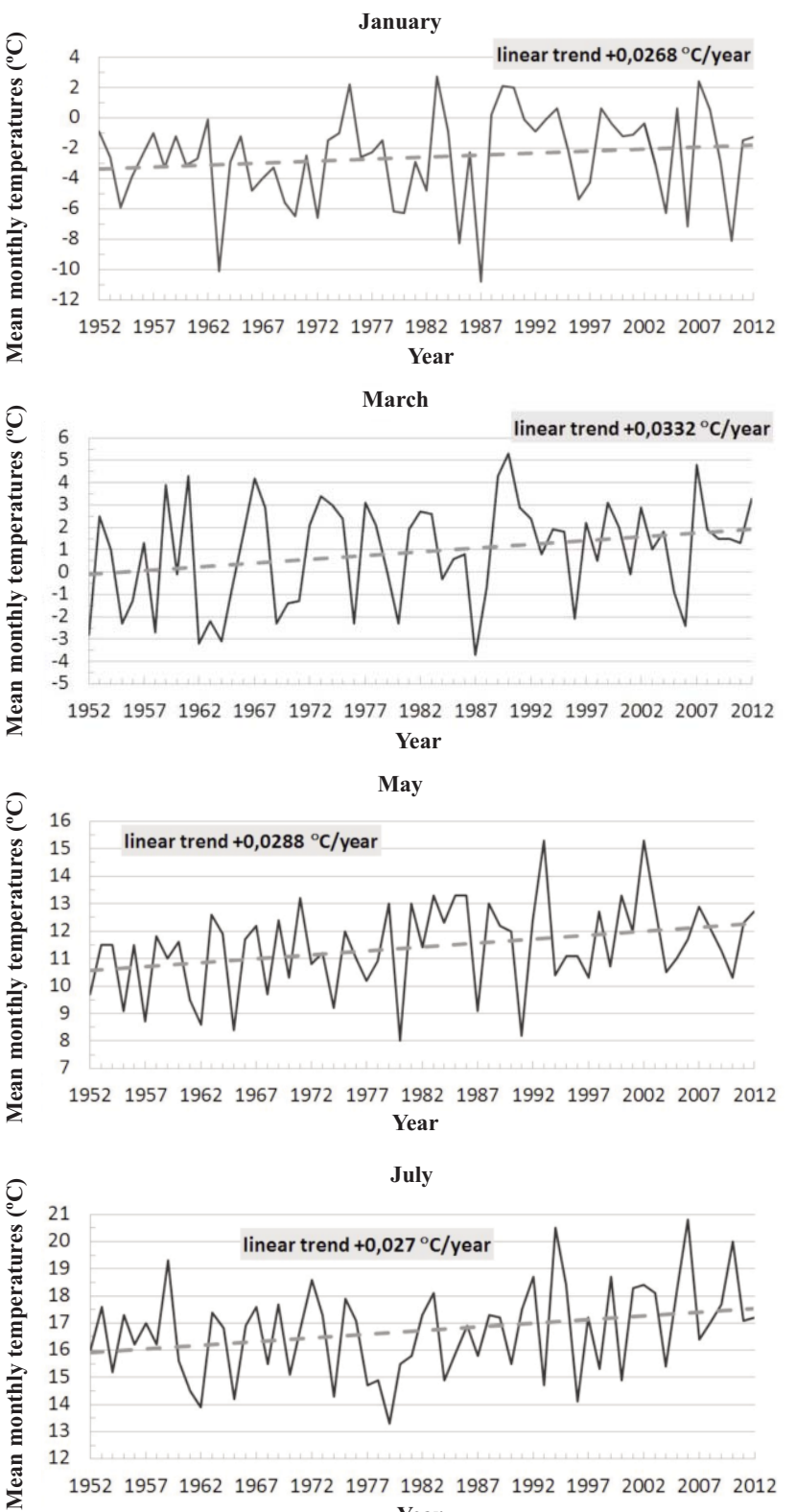
Year

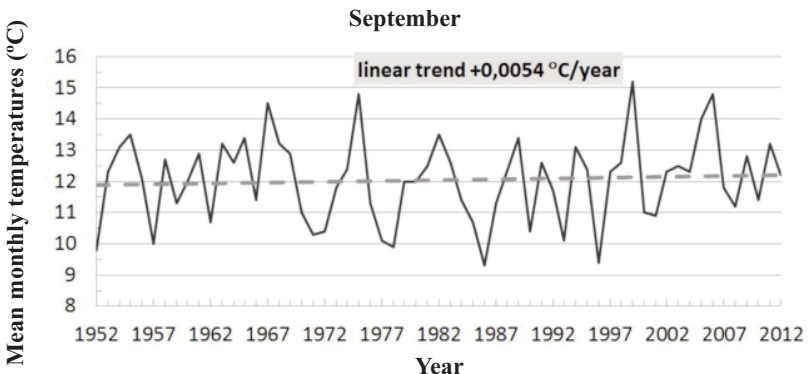
Year
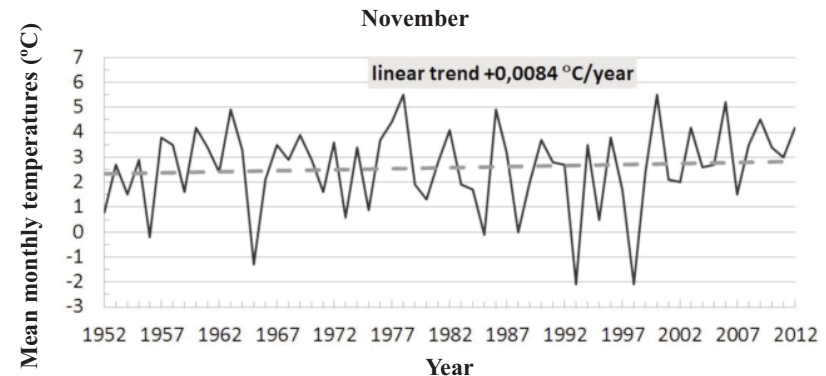

Fig. 5. Mean monthly temperatures in Koscierzyna, 1952-2012.

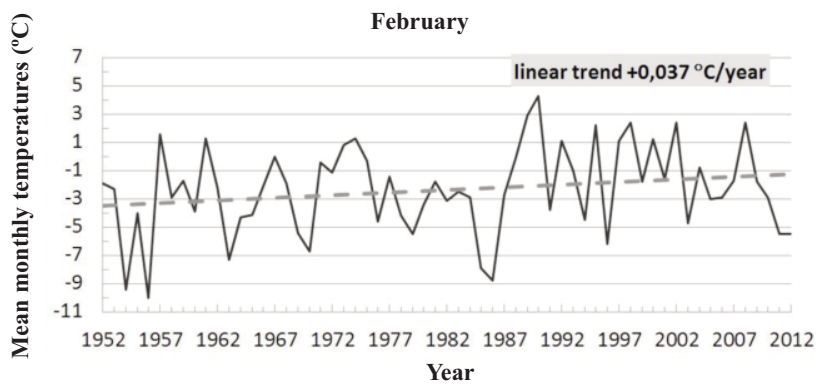

April
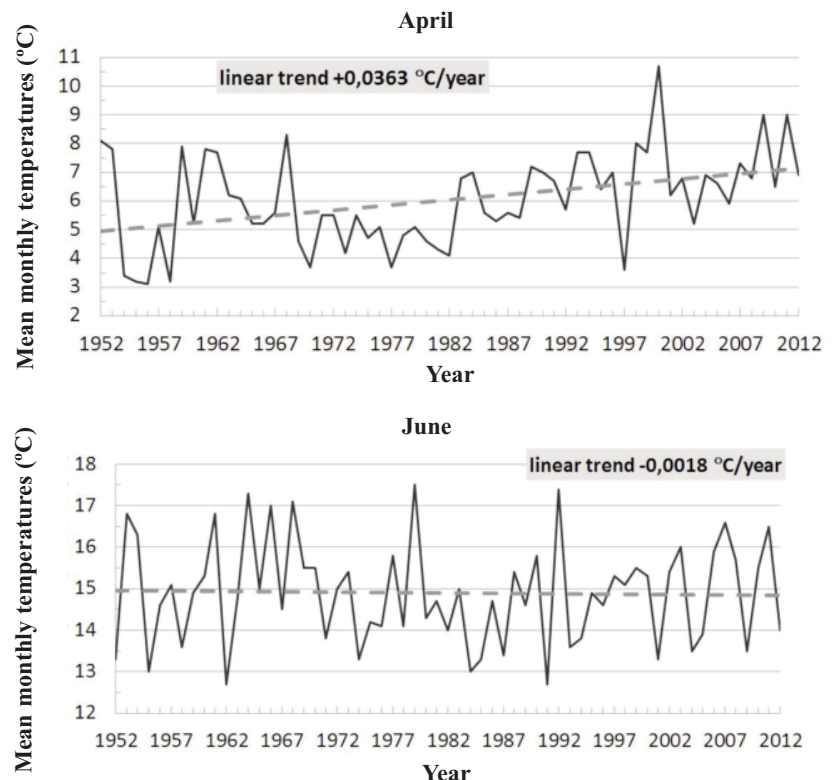

Year
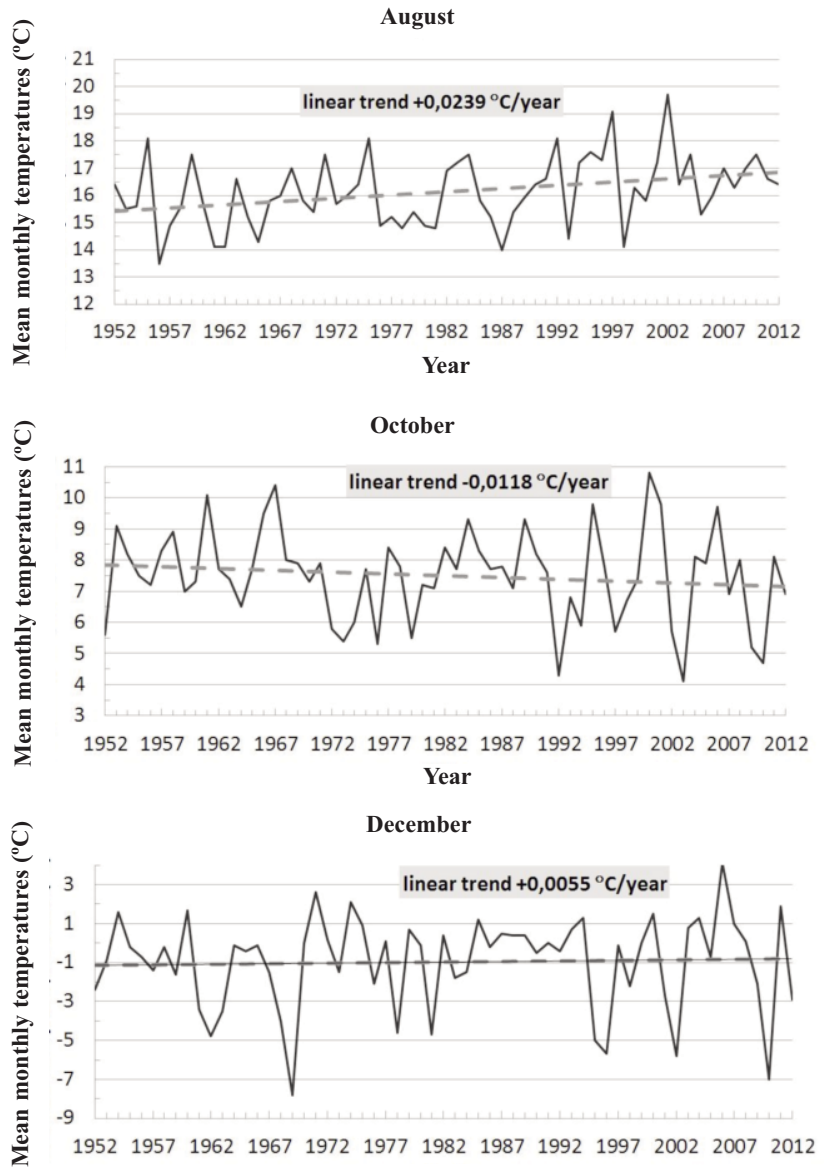
Year 
Table 3. Values of average monthly and annual precipitation totals and trends in their changes for the weather station in Koscierzyna, based on analysis of 1952-2012.

\begin{tabular}{|c|c|c|c|c|c|c|c|c|}
\hline \multirow[t]{2}{*}{ Time } & $\begin{array}{c}\text { Average } \\
\text { monthly and } \\
\text { annual precip- }\end{array}$ & $\begin{array}{l}\text { Maximum } \\
\text { monthly and } \\
\text { annual precip- }\end{array}$ & $\begin{array}{l}\text { Minimum } \\
\text { monthly and } \\
\text { annual precip- }\end{array}$ & \multirow{2}{*}{$\begin{array}{c}\text { Trend in } \\
\text { precipitation } \\
\text { totals } \\
\text { changes }\end{array}$} & \multicolumn{2}{|c|}{$\begin{array}{l}\text { Possible change in } \\
\text { precipitation totals } \\
\text { over } 50 \text { years }\end{array}$} & \multirow{2}{*}{$\begin{array}{l}\text { Terrain evapora- } \\
\text { tion in Borucino } \\
\text { Station } \\
\text { \% of precipitation }\end{array}$} & \multirow{2}{*}{$\begin{array}{l}\text { Increase of precipi- } \\
\text { tation involved in } \\
\text { the groundwater } \\
\text { recharge }\end{array}$} \\
\hline & \multicolumn{3}{|c|}{$\mathrm{mm}$} & & $\mathrm{mm}$ & $\%$ & & \\
\hline I & 43.93 & 160.70 & 2.90 & 0.375 & 18.75 & 42.68 & \multirow{4}{*}{ not measured } & \multirow{4}{*}{$+46.66 \mathrm{~mm}$} \\
\hline II & 35.08 & 89.70 & 4.30 & 0.1298 & 6.49 & 18.50 & & \\
\hline III & 36.94 & 109.80 & 4.20 & 0.472 & 23.6 & 63.89 & & \\
\hline IV & 35.14 & 102.00 & 0.70 & -0.0435 & -2.175 & -6.19 & & \\
\hline V & 58.82 & 130.80 & 10.40 & 0.1944 & 9.72 & 16.52 & 155.5 & \multirow{6}{*}{ growing season } \\
\hline VI & 71.11 & 230.40 & 1.20 & 0.1551 & 7.755 & 10.91 & 120.8 & \\
\hline VII & 84.06 & 227.70 & 8.00 & 0.1457 & 7.285 & 8.67 & 73.7 & \\
\hline VIII & 70.38 & 154.20 & 4.60 & -0.0241 & -1.205 & -1.71 & 97.2 & \\
\hline IX & 62.50 & 144.70 & 3.40 & -0.0778 & -3.89 & -6.22 & 64.4 & \\
\hline $\mathrm{X}$ & 51.22 & 132.80 & 6.60 & 0.2494 & 12.47 & 24.35 & 54.9 & \\
\hline XI & 55.50 & 136.80 & 10.80 & 0.1038 & 5.19 & 9.35 & \multirow{2}{*}{ not measured } & \multirow{2}{*}{$+13.55 \mathrm{~mm}$} \\
\hline XII & 50.76 & 124.50 & 8.70 & 0.1672 & 8.36 & 16.47 & & \\
\hline Year & 655.44 & 960.40 & 411.90 & 1.8472 & 92.36 & 14.09 & - & $+60.22 \mathrm{~mm}$ \\
\hline $\mathrm{V}-\mathrm{X}$ & & & & & & & 94.4 & growing season \\
\hline XI-IV & & & & & & & 40 & non-growing season \\
\hline
\end{tabular}

The total increase of precipitation involved in the groundwater recharge $=+60.22 \mathrm{~mm}-40 \%$ on evaporation $=+36 \mathrm{~mm}$

Table 4. Trends in surface temperature and trends in annual precipitation over land in northern Poland taken from the map of the IPPC report [3].

\begin{tabular}{|c|c|c|c|}
\hline \multirow{2}{*}{ Data set } & \multicolumn{3}{|c|}{ Temperature trends in ${ }^{\circ} \mathrm{C}$ per decade } \\
\hline & $1901-2012$ & $1951-1980$ & $1981-2012$ \\
\hline HadCRUT4 [16] & +0.09 & - & - \\
\hline NCDC MLOST [17] & +0.14 & +0.1 & +0.4 \\
\hline GISS [18] & +0.11 & - & - \\
\hline \multirow{2}{*}{ Data set } & \multicolumn{3}{|c|}{ Annual precipitation trends in $\mathrm{mm}$ per decade } \\
\hline & \multicolumn{3}{|c|}{$1951-2010$} \\
\hline CRU TS 3.10.01 (updated from Mitchell and Jones [19]) & \multicolumn{3}{|c|}{$+2.5-5.0$} \\
\hline GPCC V6 [20] & \multicolumn{3}{|c|}{$+10.0-25.0$} \\
\hline
\end{tabular}

from November to April evaporation is about $40 \%$ of precipitation (Table 3). On this basis, it can be assumed that if current trends are maintained - the sum of precipitation involved in the groundwater recharge will rise.

The positive trends in temperature can also have a significant impact on groundwater resources. The temperature increase during the winter months will reduce the depth of soil freezing and the formation of snow cover. These factors affect increased infiltration of melting snow and a marked increase in groundwater outflow [14].

The overall increase in precipitation for the period beyond the growing season is about $60 \mathrm{~mm}$ (Table 3). Taking into account the 40 percent of evaporation during this period, it can be assumed that the precipitation involved in the groundwater recharge will likely increase by $36 \mathrm{~mm}$ $(5.5 \%)$ over the next 50 years (Table 3$)$. Another factor con- 

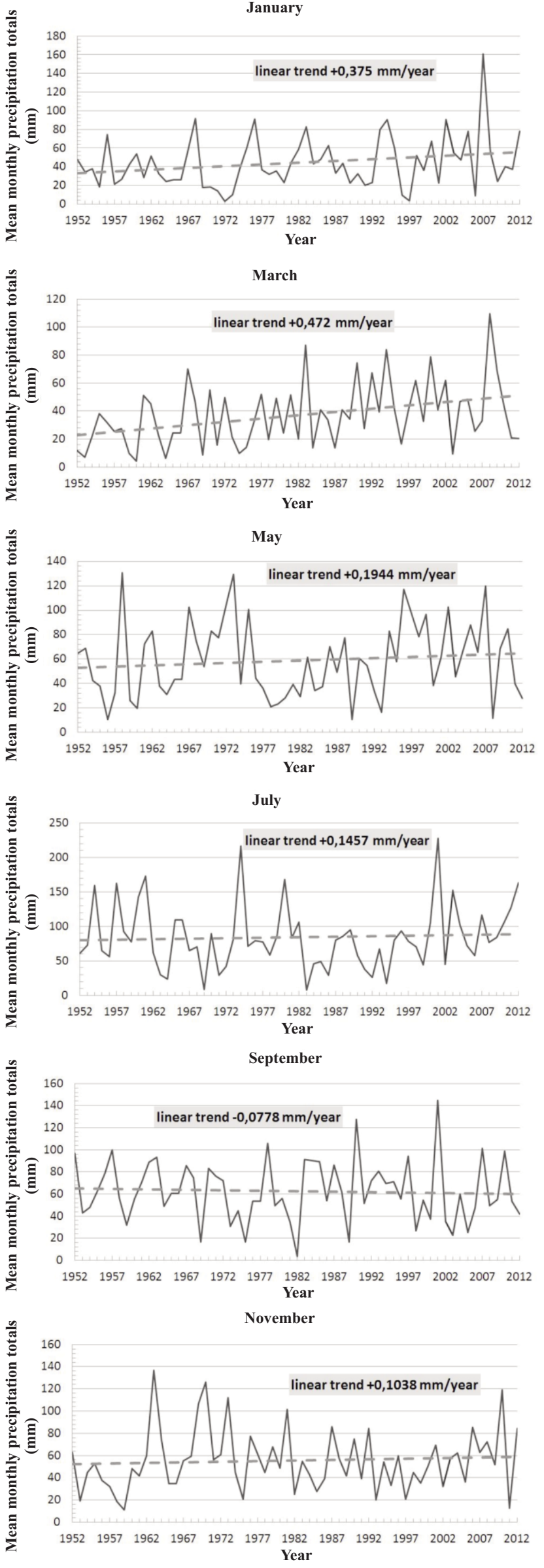

Fig. 6. Mean monthly precipitation totals in Koscierzyna, 1952-2012.
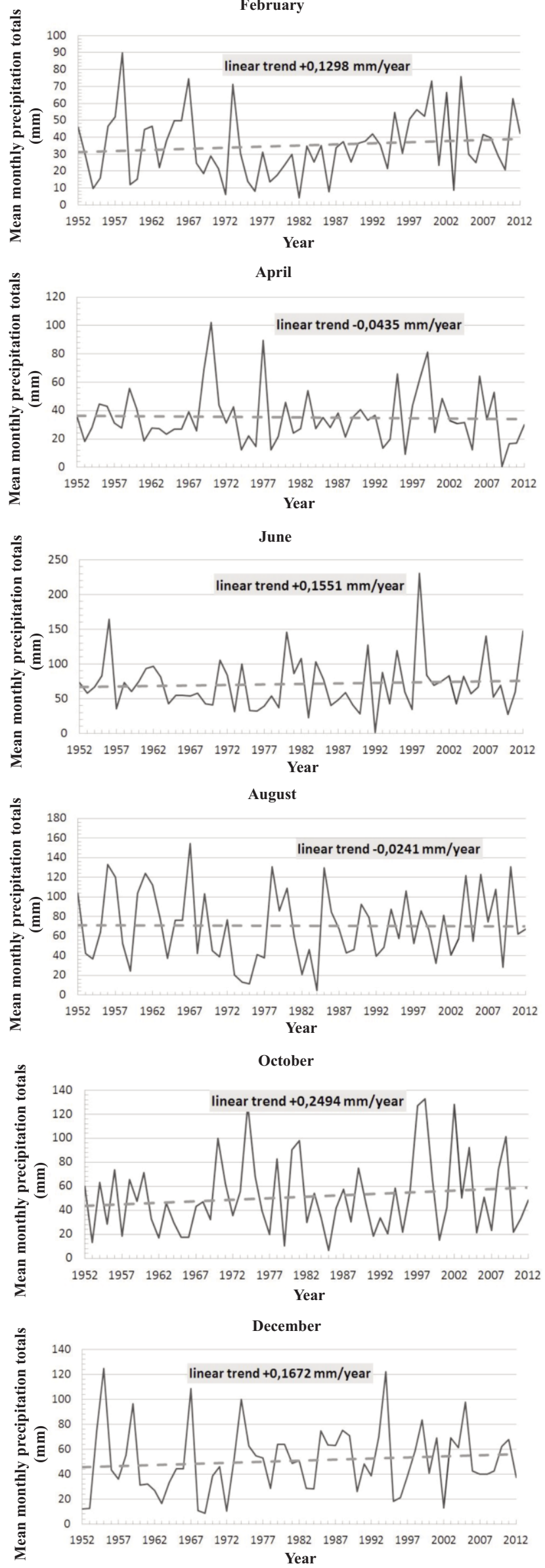
tributing to the increased infiltration could be the expected [15] rise in temperatures in winter months - also consistent with the trends for Koscierzyna Station. However, it is difficult to estimate the value of the increased infiltration due to the temperature increase and melting snow infiltration. But it is undoubtedly a favorable factor. It should be emphasized that the presented scenario is based on the assumption of current trends continuing, which is an obvious simplification due to dynamic climate change.

In light of these projections, an annual recharge from precipitation increase of $5.5 \%$ was simulated and the impact of this on groundwater resources was analysed. The model calculation results (Fig. 3) showed that:

- The entire multi-aquifer system shows a tendency for increased descending seepage between aquifers as well as slightly reduced ascent seepage; in this way descent recharge to deeper aquifers increases from $2 \%$ to $5 \%$ and upward flow decreases less than $1 \%$

- The infiltration of surface waters is reduced from $1 \%$ in the second aquifer to $11 \%$ in the first aquifer (perched groundwater); outflow slightly increases by about $1 \%$

- Spring outflow at the valley level (the third aquifer) increases by $4.2 \%$, and in the first layer more than $12 \%$

- In the deeper aquifers the lateral inflow decreases from 2 to $5 \%$ and the outflow toward the drainage base increases by about $2.5 \%$

- The groundwater level is likely to increase by $0.7 \mathrm{~m}$ in the outwash sand layer (the second aquifer), and about $1.2 \mathrm{~m}$ in the perched groundwater layer (the first aquifer)

\section{Conclusion}

Characteristic features of young glacial aquifer systems is the multiple aquifers and aquitards occurrence. As a result, recharge from the infiltration of precipitation goes directly to various aquifers due to the large variation in the morphology and the spatial complexity of the aquifers.

This article analyses the impact of projected changes in temperature and precipitation on groundwater resources. The analysis carried out for the six-decade period (19522012) shows the temperature increase of $+0.0182^{\circ} \mathrm{C} /$ year. The highest increase in temperature is observed in the months from January to May, and in July and August. The analysis of the average monthly and annual precipitation also shows a growing trend of on average 1.847 $\mathrm{mm} /$ year. The largest increase relates to the months from January to March and from October to December. These positive trends in temperature and precipitation may contribute to an increase in groundwater recharge - primarily because of the precipitation increase in the non-growing season and the temperature increase in the winter months, which contributes to increased infiltration of melting snow.

If the current trends continue the sum of precipitation involved in groundwater recharge will probably increase by $36 \mathrm{~mm}(5.5 \%)$ over the next 50 years, which is consistent with the projected trends in the IPCC reports for this region. The model calculation made for these projections showed primarily a tendency for increased (up to 5\%) descent seepage between aquifers and a slight decrease (less than 1\%) in the upward flow. The most significant changes are observed in the first layer, were spring outflow increases by $12 \%$. The infiltration of surface waters is reduced and the outflow slightly increases. The groundwater table is likely to rise from $0.7 \mathrm{~m}$ in the second aquifer up to $1.2 \mathrm{~m}$ in the perched groundwater layer (the first aquifer).

\section{Acknowledgements}

The research reported in this paper was supported by the Polish Ministry of Science and Higher Education, National Science Center under grant No. N N307 404538.

\section{References}

1. GREEN T.R., TANIGUCHI M., KOOI H., GURDAK J.J., ALLEN D.M., HISCOCK K.M., TREIDEL H., AURELI A. Beneath the surface of global change: Impacts of climate change on groundwater. J. Hydrol. 405, 532, 2011.

2. IPCC Climate Change Impacts, Adaptation and Vulnerability. Contribution of Working Group II to the Fourth Assessment Report of the Intergovernmental Panel on Climate Change, Cambridge, University Press, 2007.

3. IPCC Climate Change. The Physical Science Basis. Working Group I Contribution to the Fifth Assessment Report of the Intergovernmental Panel on Climate Change, Cambridge, University Press, 2013.

4. JACKSON C.R., MEISTER R., PRUDHOMME C. Modelling the effects of climate change and its uncertainty on UK Chalk groundwater resources from an ensemble of global climate model projections. J. Hydrol. 399, 12, 2011.

5. TAYLOR R.G., SCANLON B., DÖLL P., RODELL M., VAN BEEK R., WADA Y., LONGUEVERGENE L., LABLANC M., FAMIGLIETTI J.S., EDMUNDS M., KONIKOW L., GREEN T.R., CHEN J., TANIGUCHI M., BIERKENS M.F.P., MACDONALD A., FAN Y., MAXWELL R.M., YECHIELI Y., GURDAK J.J., ALLEN D.M., SHAMSUDDUHA M., HISCICK K., YEH P.J.F., HOLMAN I., TREIDEL H. Groundwater and climate change. Nature Climate Change 3, 322, 2013.

6. BEVEN K.J. I believe in climate change but how precautionary do we need to be in planning for the future? Hydrol. Process. 25, 1517, 2011.

7. HOLMAN I.P., ALLEN D.M., CUTHBERT M.O., GODERNIAUX P. Towards best practice for assessing the impacts of climate change on groundwater. Hydrogeol. J. 20, $1,2012$.

8. HARBAUGH A.W. MODFLOW-2005, The U.S. Geological Survey modular ground-water model - the Ground-Water Flow Process. USGS Techniques and Methods 6-A16. Reston, Virginia: U.S. Geological Survey, 2005.

9. JAWORSKA-SZULC B. Groundwater flow modeling of multi-aquifer systems for regional resources evaluation: the Gdańsk hydrogeological system, Poland. Hydrogeol. J. 17, $1521,2009$.

10. LINDER L., MARKS L. Climatostratigraphic subdivision of the Pleistocene Middle Polish Complex in Poland. Prz. Geol., 60, (1), 36, 2012. 
11. PETELSKI K., MOCZULSKA G. Description of the Geological map of Poland 1:50,000, Egiertowo no 53. Polish Geological Institute, Warsaw, Poland, 2006.

12. MIETUS M. (Ed.) Climate of Radunskie glacial channel lakes in Polish. Instytut Meteorologii i Gospodarki Wodnej, Warsaw, Poland, 2006.

13. MORIN E. To know what we cannot know: Global mapping of minimal detectable absolute trends in annual precipitation. Water Resour. Res., 47, 2011.

14. IWATA Y., HAYASHI M., SUZUKI S., HIROTA T., HASEGAWA S. Effects of snow cover on soil freezing, water movement, and snowmelt infiltration: A paired plot experiment. Water Resour. Res., 46, W09504, 2010. doi: 10.1029/2009WR008070

15. IPCC Climate Change: The physical science basis. Contribution of Working Group I to the Fourth Assessment Report of the Intergovernmental Panel on Climate Change, Cambridge, University Press, 2007.

16. MORICE C.P., KENNEDY J.J., RAYNER N.A., JONES P.D. Quantifying uncertainties in global and regional tem- perature change using an ensemble of observational estimates: The HadCRUT4 data set. J. Geophys. Res.-Atmos., 117, 22, 2012.

17. VOSE R.S., APPLEQUIST S., MENNE M.J., WILLIAMS C.N., THORNE P. An intercomparison of temperature trends in the US Historical Climatology Network and recent atmospheric reanalyses. Geophys. Res. Lett., 39, L10703, 2012.

18. HANSEN J., RUEDY R., SATO M., LO K. Global surface temperature change. Rev. Geophys., 48, RG4004, 2010.

19. MITCHELL T.D., JONES P.D. An improved method of constructing a database of monthly climate observations and associated high-resolution grids. Int. J. Climatol., 25, 693, 2005.

20. BECKER A., FINGER P., MEYER-CHRISTOFFER A., RUDOLF B., SCHAMM K., SCHNEIDER U., ZIESE M. A description of the global land-surface precipitation data products of the Global Precipitation Climatology Centre with sample applications including centennial (trend) analysis from 1901-present. Earth Syst. Sci. Data 5, 71, 2013. 
